\title{
MORPHOLOGICAL DISAMBIGUATION OF MULTIWORD EXPRESSIONS AND ITS IMPACT ON THE DISAMBIGUATION OF THEIR ENVIRONMENT IN A SENTENCE ${ }^{1}$
}

\author{
MILENA HNÁTKOVÁ - VLADIMÍR PETKEVIČ \\ Faculty of Arts, Charles University, Prague, Czech Republic
}

HNÁTKOVÁ, Milena - PETKEVIČ, Vladimír: Morphological Disambiguation of Multiword Expressions and Its Impact on the Disambiguation of Their Environment in a Sentence. Journal of Linguistics, 2017, Vol. 68, No 2, pp. 145 - 155.

\begin{abstract}
This study concerns the impact of the collocation/phraseme disambiguation component within the complex system of the rule-based morphological disambiguation of Czech. This system constitutes one of the two main disambiguation subsystems that are responsible for the morphological disambiguation of the corpora of synchronic Czech within the Czech National Corpus project. We will show that although the part of texts constituted by collocations/phrasemes (generally multiword expressions - MWEs) is relatively small and consequently the errorfree morphological disambiguation of MWEs covers only a small portion of textual material, such perfectly disambiguated fragments in sentences help to improve the disambiguation of the rest, non-MWE part of sentences.

Keywords: multiword expressions, lexical database, morphological analysis, morphological ambiguity, morphological disambiguation, process of disambiguation, Czech National Corpus
\end{abstract}

\section{INTRODUCTION}

The series of corpora of synchronic Czech within the Czech National Corpus, viz. SYN2005, SYN2010, SYN2013PUB, SYN2015, versions of SYN, ${ }^{2}$ are morphologically disambiguated by a complex process in which two main components cooperate: the rule-based disambiguation system called Lan Gr ([5], [6], [3], [4], [7], [8], [9]) and the stochastic tagger called Featurama (https://sourceforge. net/projects/featurama/). This hybrid disambiguation system is activated immediately after morphological analysis: individual morphological homographs are subject to the disambiguation of

(i) lemmas, and

(ii) morphological tags, including part-of-speech tagging.

\section{THE DISAMBIGUATION PROCESS}

The first disambiguation component, the LanGr system, consists of ca. 2600 handcrafted linguistic rules that are

${ }^{1}$ This paper was financially supported by the grant Between Lexicon and Grammar (Mezi slovníkem a gramatikou - Grant Agency of the Czech Republic, reg. no. 16-07473S).

${ }^{2}$ http: // korpus.cz 
(a) developed on the basis of linguistic introspection and checked on corpus data, and also

(b) non-automatically inferred from corpus data.

Linguistic rules are written in a special programming language and their performance consists in the context-based gradual deletion of incorrect lemmas and tags assigned to individual tokens. First, the LanGr system processes the output of morphological analysis which assigns every token all of its tags and lemmas; the recall of morphological analysis is currently $99.25 \%$. As the morphological analyzer assigns all tokens all of its lemmas and tags regardless of the context, the tokens are assigned the highest amount of incorrect tags, i.e. the precision is lowest possible on disambiguation input. The disambiguation consists in keeping the best possible recall (close to $100 \%$ ) and in gradually increasing precision by removing lemmas and tags that are incorrect in the given context.

Disambiguation rules are contained in two main groups:

a) safe rules organized in two subgroups: Safe0 containing entirely safe rules and Safe1 containing slightly less safe rules

b) heuristic rules (Heu).

An input sentence is gradually more and more disambiguated by the rules' application until - ideally - a full disambiguation is achieved, i.e. each token is assigned the only correct lemma and tag. If the rule-based tagger is unable to entirely delete all inappropriate tags and lemmas in the input sentence, the remaining incorrect ones are removed by the second disambiguation component: stochastic tagger Featurama.

The process of the rule-based morphological disambiguation also involves the collocational module Phras ([1], [2]), identifying and properly disambiguating multiword expressions (MWEs). Thus, the following modules take part in the disambiguation process:

(i) LanGr tagger based on manually written rules;

(ii) Phras module using a lexical database of maximally disambiguated MWEs;

(iii) parameterizable stochastic tagger, currently Featurama.

The cooperation of the modules consists in the following sequence of operations applied to a sentence:

$1733853790 \mathbf{1}^{\text {st }}$ step: The output of morphological analysis is processed by entirely safe rules (Safe0 group). The rules gradually disambiguate the sentence, i.e. the number of incorrect tags decreases. The process continues till there is nothing to disambiguate, i.e. till the rules in recurrent cycles exhaust their disambiguation capacity.

$17338537902^{\text {nd }}$ step: Phras module is invoked: it identifies MWEs in the sentence and performs disambiguation of their components as much as possible.

$1733853790 \mathbf{3}^{\text {rd }}$ step: The set of safe rules Safe0 is reapplied. After these rules finish their job, i.e. they are not able to disambiguate any more, the 17338537904 th step follows.

$17338537904^{\text {th }}$ step: Three sets of rules, i.e. Safe0, Safe1 and the set of heuristic rules $\mathrm{Heu}$, are applied in cycles to disambiguate the sentence till they cannot disambiguate any more; 
$1733853790 \mathbf{5}^{\text {th }}$ step: The remaining incorrect tags intact up to now by the Lan $\mathrm{Gr}$ system are removed by the stochastic tagger Featurama and a postprocessing phase (see below).

Table 1 presents a quantitative contribution (in \%) of each subsystem within the entire morphological analysis and disambiguation system, where the subsystems are as follows:

Morph - morphological analysis

Safe0 - safe rules: Safe0 (cf. $1^{\text {st }}$ and $17338537903^{\text {rd }}$ step above)

Phras - phraseme module Phras processing MWEs (cf. $17338537902^{\text {nd }}$ step above)

$\mathrm{SSH}$ - the sets of rules Safe0, Safe1 and Heu applied together (cf. 1733853790 $4^{\text {th }}$ step above)

Tagger - stochastic tagger Featurama (cf. $17338537905^{\text {th }}$ step above)

Post - postprocessing phase (verbal aspect added; possible reinterpretation of controversial part-of-speech annotation, e.g. adverb/particle; finalization of named entities processing...).

\begin{tabular}{|c|c|c|}
\hline after & \% of all tokens / incrementally & \% of all words / incrementally \\
\hline Morph & 22.07 & 25.88 \\
\hline Safe0 & $31.46 / 53,53$ & $36.88 / 62.76$ \\
\hline Phras & $\mathbf{0 . 6 9} / \mathbf{5 4 . 2 2}$ & $\mathbf{0 . 8 0} / \mathbf{6 3 . 5 6}$ \\
\hline Safe0 & $\mathbf{2 . 1 7} / \mathbf{5 6 . 3 9}$ & $\mathbf{2 . 5 4} / \mathbf{6 6 . 1 0}$ \\
\hline SSH & $6.55 / 62.94$ & $7.68 / 73.78$ \\
\hline Tagger & $22.13 / 85.07$ & $25.94 / 99.72$ \\
\hline Post & $0.23 / 85.30$ & $0.27 / 99.99$ \\
\hline
\end{tabular}

Tab. 1. Contribution of individual subsystems to the entire disambiguation of the texts contained in the sample Newton corpus of journalistic texts (the size in tokens including punctuation marks: 1735482 098; words: 1480369 445). The contribution is measured merely by the number of achieved unambiguous tags assigned to words after each phase of processing, the quality of disambiguation (recall and precision in the strict sense of the word) is not accounted for here.

In the middle column, the ratio of fully disambiguated tags of words in $\%$ after each phase of processing is presented with respect to all tokens (= all corpus positions including punctuation). In the right column, the ratio with respect to word forms only (i.e. without punctuation) is shown. Thus, morphological analysis identifies $22.07 \%$ of all tokens and $25.88 \%$ of all words as morphologically unambiguous word forms. The Safe0 rule group is able to disambiguate further $31.46 \%$ words that were ambiguous after morphological analysis etc. till all words $(=85.30 \%$ of all tokens) are unambiguously disambiguated (the rest of the tokens, i.e. $14.70 \%$, is constituted by punctuation tokens). The figures in the right column have the same meaning as in the middle column but they are counted with respect to words only.

Table 2 shows the average number of tags assigned to tokens (words + punctuation marks) after each stage of processing. The figures in the second column mean that the average number of tags assigned to tokens by morphological analysis is almost 11; if punctuation is not taken into account the average number is 12.28 , 
and if only ambiguous words are considered, the average number is more than 16 . Table 2 demonstrates the paramount importance of the Safe 0 set of rules that is able to decrease the average number of tags assigned by morphological analysis to tokens, words and ambiguous words to $2.81,3.08$ and 5.80, respectively.

\begin{tabular}{|l|c|c|c|}
\hline after & All tokens counted & only words counted & only ambiguous words counted \\
\hline Morph & 10.62 & 12.28 & 16.21 \\
\hline Safe 0 & 2.81 & 3.08 & 5.80 \\
\hline Phras & $\mathbf{2 . 7 6}$ & $\mathbf{3 . 0 3}$ & $\mathbf{5 . 7 5}$ \\
\hline Safe0 & $\mathbf{2 . 5 4}$ & $\mathbf{2 . 7 7}$ & $\mathbf{5 . 4 0}$ \\
\hline SSH & 1.92 & 2.04 & 4.17 \\
\hline
\end{tabular}

Tab. 2. Average number of tags per word form achieved in the same annotated Newton corpus

Table 1 and Table 2 present, in fact, the measure of precision in a very coarse way since only the ratio of deleted tags in $\%$ is shown without taking into account whether only incorrect tags were deleted.

In Table 3 we present the recall after each processing step.

\begin{tabular}{|l|l|}
\hline after & recall \\
\hline Morph & $99.25 \%$ \\
\hline Safe0 & $99.09 \%$ \\
\hline Phras & $\mathbf{9 9 . 0 7 \%}$ \\
\hline SSH & $98.82 \%$ \\
\hline
\end{tabular}

Tab. 3. The recall of (i) the morphological analyzer (Morph), (ii) the safe rules (Safe0), (iii) the MWE module (Phras), (iv) Safe0+Safe1+Heu(ristic) rules (SSH)

We see that the recall decreases very slightly: Safe 0 rules make only $0.16 \%$ errors, the error rate of the MWE module is only $0.02 \%$. The entire rule-base disambiguation system decreases recall after morphological analysis by only $0.43 \%$ (99.25-98.82).

The accuracy (recall + precision) of the entire disambiguation system, i.e. including the Featurama tagger and the postprocessing phase Post, is ca. 95.1\%.

It is to be noted that the disambiguation system described above is not used in syntactic parsing. Stochastic parsers applied to Czech reduce morphological ambiguity to a large extent but the recall they achieve in morphological disambiguation proper is always lower (ca. 93\%) than the recall of the system just depicted.

\section{THE PHRAS MODULE}

Now we will focus on the Phras module disambiguating MWEs in more detail. In Table 1 we see that it contributes to the overall disambiguation success rate only marginally $(0.69 \%)$. However, if Phras is applied, i.e. if a sentence contains a MWE that is contained in the MWE lexical database exploited by Phras, it paves the way for the Safe0 rules that are able to remove further $2.17 \%$ tags thus allowing for 
further disambiguation. The average number of tags assigned to tokens, words and ambiguous words decreases by $0.05 \%$ (cf. Table 2 ) after the Phras module is invoked.

The performance of the Phras module will be demonstrated on examples (taken from sentences contained primarily in the SYN2015 corpus) showing how Phras

(i) disambiguates MWEs themselves (par. 3.1),

(ii) contributes to the disambiguation of the environment of MWEs in a sentence (par. 3.2).

\subsection{Disambiguation of MWEs}

Phras exploits the lexical database of fully or partially disambiguated MWEs. The fixed part of these expressions is fully disambiguated, the variable inflectional part is disambiguated only partially, but as much as possible. We will present two motivating examples demonstrating part-of-speech and case disambiguation.

\section{Example 1}

In the MWE

(1) brány pekla

gates $_{\text {Noun-Npl.Fem/Apl.Fem/Vpl.Fem }}$ of_hell $1_{\text {Noun.Gsg.Neut }}$

there is a word form brány 'gates' 1733853794 that is, morphologically, part-ofspeech ambiguous - it is:

(i) genitive singular (Gsg), or nominative/accusative/vocative plural (Npl/Apl/ $\mathrm{Vpl})^{3}$ of the feminine noun brána 'gate'

(ii) passive participle in feminine plural / masculine inanimate plural of the verb brát 'take'.

In (1), the form brány is, however, a part-of-speech unambiguous feminine noun in plural and three cases: $\mathrm{Npl} / \mathrm{Apl} / \mathrm{Vpl}$ since the entirely unambiguous morphological interpretation depends on a textual context.

The other word in (1), pekla, is also part-of-speech ambiguous since it is:

(i) $\mathrm{Gsg} / \mathrm{Npl} / \mathrm{Apl} / \mathrm{Vpl}$ of the neuter noun peklo 'hell'

(ii) past participle in feminine singular / neuter plural of the verb péci 'bake'.

In (1), the word form pekla is unambiguous: Gsg of the neuter noun peklo.

\section{Example 2}

In the MWE lexical database entry for the MWE,

(2) ekonomický růst

economic $_{\text {Adj-Nsg.MascInan/Asg.MascInan }}$ growth Noun-Nsg.MascInan/Asg.MascInan $_{\text {nat. }}$ 'economic growth'

the form ekonomický 'economic' is a part-of-speech unambiguous adjective in Nsg/ Asg masculine inanimate; the part-of-speech ambiguous form rist 'growth / to grow' is disambiguated as a masculine inanimate noun in Nsg/Asg ('growth'), rather than the infinitive of the verb ('to grow'). Moreover, this database entry contains information that both forms agree in number, gender and case.

The Phras module is also very helpful in disambiguating proverbs and other sentential idioms as is shown in the following example.

${ }^{3}$ The remaining cases in the declension system of Czech are: dative (D), locative (L) and instrumental (I). 


\section{Example 3}

In the process of morphological disambiguation, the proverb:

(3) Komu není rady, tomu není pomoci.

To_whom is_not advice Gsg.Fem $_{\text {, }}$ to_that ${ }_{\text {DsgMasc }}$ is_not help Gsg.Fem $_{\text {. }}$.

'There are none so deaf as those who will not hear'

contained in the MWE lexical database is first processed by the Safe 0 rules. They cannot cope with two nouns in the genitive of negation (constructions with the genitive of negation are rare in modern Czech, being associated only with a limited set of nouns), namely $\mathrm{rady}_{\mathrm{Gsg} . \mathrm{Fem}}$ 'advice' and pomoci $i_{\text {Gsg.Fem }}$ 'help', because the word rady and pomoci can also be a form of the masculine animate noun rada 'counsellor' and the infinitival form of the verb pomoci 'to help', respectively. Moreover, the form tomu 'to that' is not only dative singular (Dsg) masculine form of the pronoun ten 'that', but also Dsg neuter form of the pronoun to 'it'. The collocational module resolves all these ambiguities and entirely disambiguates the proverb.

\subsection{Disambiguation of MWEs' Context}

On several examples, we will show how disambiguation of MWEs performed by the Phras module can improve disambiguation of their sentential context. These randomly chosen examples are to elucidate the main objectives of the disambiguation of MWEs and of their content: part-of-speech disambiguation, primarily deciding between nouns, verbs and adjectives, and case disambiguation (concerning nouns, adjectives, pronouns and numerals), which is the most difficult subtask of the whole disambiguation process.

\section{Example 4}

In sentence:

(4) Asadův režim nenese odpovědnost za použití zbrani hromadného ničení.

Asad régime Noun.Nsg.Masclnan $_{\text {not_bears }}$ responsibility ${ }_{\text {Noun.Asg.Fem }}$ for exploitation of weapons of_mass destruction.

'Asad régime does not bear responsibility for the exploitation of the weapons of mass destruction.'

Phras identifies the pair nenese odpovédnost ('not_bears responsibility') of the MWE nést odpovědnost 'bear responsibility' and disambiguates its components. The unambiguous present $3^{\text {rd }}$ person singular negative form nenese of the transitive verb nést 'bear' poses no disambiguation problem, but the feminine noun odpovédnost 'responsibility' can morphologically be Nsg/Asg. The masculine inanimate noun režim 'régime' is case ambiguous in the same way. As the disambiguated MWE is contained in the MWE lexical database, Phras unequivocally disambiguates odpovédnost in (4) as Asg. The general rules cannot solve, on the basis of sole syntax, the classical disambiguation problem in Czech consisting in the disambiguation of the pattern:

Noun $1_{\text {Nom/Acc }} \quad$ Verb Trans.Pres.3rd.Sg $_{\text {Noun }} 2_{\text {Nom/Acc }}$ where either Noun1 and Noun2 is in the nominative and accusative case, respectively, or vice versa.

As Phras disambiguates odpovédnost as Asg, it fundamentally helps to disambiguate the sentence: as odpovědnost is in Asg, the noun režim 'régime' cannot 
be in non-prepositional Asg (the valency of the verb nést does not admit two accusative objects and, moreover, the noun odpovédnost cannot head an accusative nominal phrase having the syntactic function of adverbial) and that is why it is in Nsg. After such a correct disambiguation, it is then, e.g., no problem for a parser of Czech to assign proper syntactic functions to the nominal phrase Asadiov režim 'Asad régime' (= subject) and to the nominal phrase odpovédnost 'responsibility' (= object). Thus the rest of the sentence is also influenced: there are no non-prepositional nouns as objects in accusative ${ }^{4}$ in the sentence. In particular, the word ničeni 'destruction' cannot be in non-prepositional accusative. The importance of the disambiguation of the MWE nést odpovédnost is thus clearly demonstrated. There are many such support verb (verbo-nominal) constructions in Czech as nést odpovédnost and the more such constructions are contained in the MWE lexical database, the better ad more accurate Phras is ${ }^{5}$. The disambiguation of such support verb constructions is of paramount importance especially in cases where some of the collocation components are not only case ambiguous (as in odpovědnost) but even part-of-speech ambiguous:

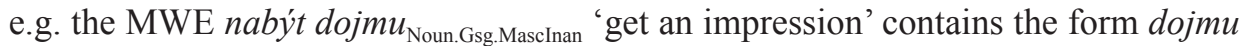
that is morphologically Gsg/Dsg/Lsg of the masculine inanimate noun dojem 'impression', or 1st person singular present tense of the verb dojmout 'impress'; the verbo-nominal construction $m a_{\text {Trans.Pres.3rd.Sg }}$ štéstí (lit. 'has happiness' '(s)he is lucky') contains the part-of-speech ambiguous word má (morphologically either $3^{\text {rd }}$ person singular present tense of the verb mit 'have', or Nsg.Fem/Npl.Neut/Apl.Neut/Vpl. Neut of the possessive pronoun mij 'my'; the verbo-nominal construction svalit $v i n u_{\text {Noun.Asg.Fem }}$ 'throw the blame (for something on someone)' contains the part-ofspeech ambiguous word vinu (morphologically, the form vinu is either Asg of the feminine noun vina 'guilt', or $17338537961^{\text {st }}$ person singular present tense of the reflexive verb vinout se, 'to wind') etc. If such words were erroneously part-ofspeech disambiguated, undoubtedly the disambiguation of other words in sentences containing such MWEs would be badly affected.

\section{Example 5}

In sentence:

(5) Manželé přijedou na plzeňské hlavní nádraží parním vlakem.

Married_couple will_arrive to Prep.Acc $_{\text {Pilsen }}$ Adj.Asg.Neut $_{\text {main }_{\text {Adj.Asg.Neut }}}$ railway_station Noun. $_{\text {. }}$ Asg.Neut by steam engine.

'The married couple will arrive at Pilsen main railway station by steam engine.'

there is a frequent collocation hlavní nádraži 'main railway station', where the word hlavní 'main' is an adjective agreeing with the noun nádraži 'railway station' in number (singular/plural), gender (neuter) and case (nominative/accusative/vocative). However, it can also be a form of the feminine noun hlaveň 'barrel' in Isg/Gpl. If the

\footnotetext{
${ }^{4}$ Generally, nominal phrases can also head adverbials of time (duration) or regard in accusative as their attributes, but the set of head nouns governing such adverbials is limited.

${ }^{5}$ Some examples of support verb constructions: vynést rozsudek 'pronounce judgement', upirat zrak 'fix one's eyes on someone', nabýt dojmu 'get an impression', mit štěstí 'be lucky', mít smysl 'have sense', mit pocit 'have a feeling', mit právo 'be entitled to', mít naději 'have a hope', dávat prednost 'have preference (for something)', svalit vinu 'throw the blame (for something) on someone', učinit rozhodnuti' 'make a decision'...)
} 
disambiguation system chose this nominal interpretation of the word hlavni rather than the adjectival one, the disambiguation of the context would be wrong: the prepositional phrase (PP) na plzeňské hlavní nádraží (lit. 'to Pilsen main railway station') would be incorrectly split into three parts:

(i) PP $n a_{\text {Prep-Acc/Loc }} p l z e n ̌ s k e_{\text {Adj }}$ 'to Pilsen'6

(ii) feminine noun hlavni 'barrel' that is morphologically in Isg/Gpl and does not agree with the PP na plzeňské in case since the preposition na generally requires accusative/locative and the adjective plzeňské morphologically is, i.a., Gsg.Fem/Dsg.Fem/Lsg.Fem/Npl.Fem/Apl.Fem/Vpl.Fem/Nsg.Neut/Asg. Neut/Vsg.Neut

(iii) neuter noun nádraži 'railway station' that is morphologically Nsg/Gsg/Dsg/ $\mathrm{Asg} / \mathrm{Vsg} / \mathrm{Lsg} / \mathrm{Npl} / \mathrm{Gpl} / \mathrm{Apl} / \mathrm{Vpl}$.

Thus, the rule-based system would not know how to disambiguate the ambiguous PP na plzeňské. Moreover, the case and number of the neuter noun nádraži could hardly be identified. If, on the contrary, Phras disambiguates hlavní nádraži as a collocation, i.e. hlavní as an adjective 'main' coforming a nominal phrase with the noun nádraží (the adjective hlavní agrees with the noun nádraži in number, gender and case), the subsequently applied rules can assume that the sequence na plzeňské hlavní nádraží complies with the PP pattern:

Prep $_{\text {Acc }}$ Adj $_{\text {Asg.Neut }}$ Adj $_{\text {Asg.Neut }}$ Noun $_{\text {Asg.Neut }}$

This means that the rules can recognize the sequence as one PP in Asg. ${ }^{7}$

\section{Example 6}

In sentence:

(6) Prioritou je zajištění odbytu.

Priority is Verb.Pres.3rd.Sg $_{\text {securing }}$ Noun.Nsg.Neut $_{\text {of__sales }}$ Noun.Gsg.Masclnan.

'The priority is the securing of sales.'

there are three part-of-speech ambiguous words:

(a) je is:

(i) 3rd person singular present tense form of the verb být 'be'

(ii) Asg of the 3rd person neuter personal pronoun ono 'it'

(iii) Apl of the 3rd personal pronoun (all genders) oni/ony/ona 'they';

(b) zajištěni is:

(i) Npl.MascAnim/Vpl.MascAnim form of the adjective zajištěny' 'secured'

(ii) $\mathrm{Nsg} / \mathrm{Gsg} / \mathrm{Dsg} / \mathrm{Asg} / \mathrm{Vsg} / \mathrm{Lsg} \ldots$ of the deverbal neuter noun zajištěni 'securing';

(c) odbytu is:

(i) Gsg/Dsg/Lsg of the masculine inanimate noun odbyt 'sales'

(ii) passive participle of the transitive verb odbýt 'do sloppily' in Asg.Fem.

General disambiguation rules can hardly correctly disambiguate the nominal phrase (NP) zajištění odbytu 'securing of sales' as well as its immediate context: the noun.

${ }^{6}$ For simplicity reasons, we omit the interpretation of the word form plzeňské as a (deadjectival)

7 They can, moreover, disambiguate plzeňské as an adjective rather than as a deadjectival noun (univerbization: plzeňské pivo 'Pilsner beer' $\rightarrow$ plzeňské 'Pilsner'). 
word je. The Phras module identifies the pair zajištěni odbytu as a collocation where zajištěni is disambiguated as a noun rather than as an adjective, and odbytu as a noun in Gsg rather than as a verbal passive form. For the subsequent rules it will then be much easier to identify the entire NP zajišténi odbytu 'securing of sales' as an NP where zajištěni is in Nsg, and also je as a verbal predicate in singular rather than as a personal pronoun.

\section{Example 7}

The sentence:

(7) Nasypala dovnitř prací prášek.

She poured inside Adv $_{\text {washing }}$ Adj.Asg.MascInan $_{\text {powder }}$ Noun.Asg.MascInan $_{\text {. }}$

'She poured inside the washing powder.'

is difficult to disambiguate since there are two part-of-speech ambiguous forms (dovnitř 'inside / into', praci 'washing / of-works'), and especially in such structures the processing of collocations can be very helpful. The word dovnitr is either (i) a preposition ('into') requiring genitive, or (ii) an adverb ('inside'); the word prací is either (i) Isg/Gpl form of the feminine noun práce 'work', or (ii) a very number-case ambiguous form of the soft adjective (the root ending in -i) praci 'washing'. The rules could incorrectly identify the form praci as Noun.Gpl.Fem 'work', and the word form dovnitř as a preposition taking genitive and thus the pair dovnitř prací could be identified as a genitive prepositional phrase with the meaning 'into the works'. If, on the contrary, Phras correctly identifies the pair praci prášek as a noun phrase ('washing powder') contained in the lexical database where praci is an adjective agreeing with the noun prášek in number (= singular), gender (= masculine inanimate) and case (= nominative/accusative), the subsequent rules will exclude dovnitř as a preposition taking genitive, thus interpreting dovnitř only as an adverb.

\section{Example 8}

The word misto is ambiguous between a noun 'place' and a preposition 'instead of'. A correct disambiguation of this very frequent word is crucial for the errorfree disambiguation of clauses where the word misto appears. The main disambiguation problem consists in that the noun misto often collocates with a NP in the genitive case and the preposition misto takes genitive, too. If typical collocations with the noun misto are contained in the MWE lexical database exploited by the Phras module, the disambiguation of sentences containing such collocations is much better. For instance, in sentence

(8) Policie obrátila místo činu vzhưru nohama.

Police $_{\text {Noun.Nsg.Fem }}$ reversed place Noun.Asg.Neut $_{\text {of_crime }}$ Noun.Gsg.MascInan upwards with legs.

'The police put the scene of crime out of joint.'

the Phras module identifies misto as a noun rather than as a preposition since it uses a partially disambiguated collocation misto činu (lit. 'place of crime', 'scene of crime') contained in the lexical database: misto $o_{\text {Noun-Nsg.Neut/Asg.Neut } V \text { sg.Neut }}$ čin $_{\text {Noun.Gsg. }}$ Masclnan, where the components have disambiguated morphological properties as indicated. In sentence (8), the noun misto is unambiguously in Asg since it does not agree with the feminine singular predicate obrátila 'reversed' in gender and therefore 
it cannot be the subject in the nominative case. As misto is in accusative, policie 'police' cannot be in accusative (the verb obrátila cannot take two objects in accusative), it can only be in Nsg (correct), or Gsg/Vsg (incorrect), or Npl/Apl/Vpl (incorrect). If misto were erroneously identified as a preposition, the accusative reading of the form policie could not be syntactically excluded.

Most frequent right nominal collocations with the noun misto are as follows: místo určeni ${ }^{8}$ 'destination', místo činu 'scene of crime', místo nehody 'accident site', místo konání 'venue', místo narozeni 'place of birth', místo nálezu 'place of finding', místo spolujezdce 'passenger seat', misto odpočinku 'resting place'. Such collocations contained in the lexical database and exploited by the Phras module often help to disambiguate the context of these collocations.

\section{Example 9}

In sentence:

(9) К̌ě je o dobrovolných dárcích krve.

Talk is about voluntary Adj.Lpl.MascAnim donors $_{\text {Noun.Lpl.MascAnim }}$ of blood $_{\text {Noun.Gsg.Fem. }}$

'Voluntary blood donors are being talked about.'

the Phras module identifies dárcích as Lpl of the masculine animate noun dárce 'donor' since it is a component of the MWE dárce Noun.MascAnim $_{k r v e_{\text {Noun.Gsg.Fem }}}$ 'blood donor'. In the nominal Lpl phrase o dobrovolných dárcich krve 'about voluntary donors of blood' the adjective dobrovolny'ch 'voluntary' is also in Lpl.MascAnim (due to agreement with dárcích in number, gender and case). However, the form dárcích is, morphologically, also Lpl form of the masculine inanimate noun dárek 'present'. Without knowing the existence of the MWE dárce krve the rules could erroneously disambiguate and lemmatize the form dárcích as a Lpl.MascInan form of dárek. If so, the form dobrovolných 'voluntary' would then be erroneously also disambiguated as Lpl.MascInan (due to agreement). Moreover, the morphologically ambiguous form krve is correctly disambiguated as Gsg.

\section{CONCLUSION}

In the paper, we have demonstrated the significance of MWEs' morphological disambiguation - performed by a special Phras module on the basis of a lexical database containing (partially) disambiguated MWEs - for the successful disambiguation of the other, non-MWE parts of sentences containing MWEs, the disambiguation being performed by subsequent disambiguation rules. Further work will consist in improving the collaboration of the Phras module with the general rules as to the division of labour: which MWEs are to be processed by general rules and which should be included in the lexical database and processed by the Phras module. Furthermore, the database will constantly be enhanced.

${ }^{8}$ The neuter nominal forms určení ('destination') and narození ('birth') in bold are, generally, part-of-speech ambiguous: they are also adjectives ('determined' and 'born') in Npl.MascAnim/Vpl. MascAnim. 


\section{References}

[1] Hnátková, M. (2006). Typy a povaha komponentů neslovesných frazémů z hlediska lexikálního obsazení (Types and nature of components of non-verbal phrasemes from the viewpoint of lexical elements). In Kolokace. Studie z korpusové lingvistiky, pages 142-167, Nakladatelství Lidové noviny - Ústav Českého národního korpusu, Praha.

[2] Hnátková, M. and Kopřivová, M. (2014). From Dictionary to Corpus. In Jesenšek, V. and Grzybek, P., editors, Phraseology in Dictionaries and Corpora, ZORA 97, pages 155-168, Maribor, Slovenia.

[3] Jelínek, T. (2008). Nové značkování v Českém národním korpusu (New annotation in the Czech National Corpus). Naše ř reč, 91(1):13-20.

[4] Jelínek, T. and Petkevič, V. (2011). Systém jazykového značkování současné psané češtiny (The system of linguistic annotation of contemporary written Czech). In Korpusová lingvistika Praha 2011, sv. 3: Gramatika a značkování korpusů, pages 154-170, Nakladatelství Lidové noviny / Ústav Českého národního korpusu, Praha, Czech Republic.

[5] Květoň, P. (2006). Rule-Based Morphological Disambiguation (Towards a Combination of Linguistic and Stochastic Methods). PhD thesis. MFF UK, Praha.

[6] Petkevič, V. (2006). Reliable Morphological Disambiguation of Czech: Rule-Based Approach is Necessary. In Šimková, M., editor, Insight into the Slovak and Czech Corpus Linguistics, pages 26-44, Veda (Publishing House of the Slovak Academy of Sciences \& Ludovít Štúr Institute of Linguistics of the Slovak Academy of Sciences), Bratislava, Slovakia.

[7] Petkevič, V. (2014). Problémy automatické morfologické disambiguace češtiny. Naše řeč, 97(45):194-207.

[8] Petkevič, V. (2014). Ambiguity, language structures and corpora. In La linguistique (coordonné par Radimský, J. and Pešek, O., editors, Le Cercle linguistique de Prague - II. D’hier à aujourd'hui), vol. 50, 2014-2, pages 63-82, Presses Universitaires de France.

[9] Petkevič V. (2014). Morfologická homonymie v současné češtině. Nakladatelství Lidové noviny Ústav Českého národního korpusu, Praha. 